\title{
One Year Clinical Evaluation of E-max Press Crowns Retained with Fiber Reinforced Composite Post Versus E-max Press Endocrowns in Anterior Endodontically Treated Teeth (A Randomized Clinical Trial)
}

Avaliação Clínica de um Ano de Coroas E-Max Retidas Com Resina Composta Reforçada Por Fibra Versus Endocrowns De E-Max em Dentes Anteriores Tratados Endodonticamente: Um Ensaio Clínico Randomizado

Yasmin Abou EL-ENEIN ${ }^{1}$, Jylan ELGUINDY ${ }^{2}$, Amina A ZAKI ${ }^{3}$

1 - Faculty of Oral and Dental Medicine- Egyptian Russian University- Cairo- Egypt.

2 - Faculty of Dentistry- Cairo University and Vice Dean for Education and Students Affairs- Nahda university- Cairo- Egypt.

3 - Faculty of Dentistry- Cairo University and Head of the Fixed Prosthodontics Department - Faculty of Oral and Dental Medicine, Egyptian Russian University, Cairo- Egypt.

\begin{abstract}
Objective: The purpose of this study was to assess patient satisfaction, gross fracture and marginal adaptation of e.max press endocrowns versus e.max press crowns retained with Fiber reinforced composite post (FRCP) and core in upper anterior teeth. Material and methods: The present study included 24 patients seeking root canal treatment in anterior upper arch. The patients received root canal treatment (RCT) then they were randomly assigned into two groups $(n=12)$. The first group received preparation for the IPS e.max crowns retained with FRCP and core and the second group received preparation for the IPS e.max endocrowns. Press technique was used for the fabrication of both restorations using IPS e.max press ingots. Marginal integrity and gross fracture were evaluated using USPHS criteria and a questionnaire was conducted to evaluate patient satisfaction. Data were analyzed using IBM SPSS Statistics for Windows, Version 23.0. Armonk, NY: IBM Corp. Results: There was no statistical significant difference regarding gross fracture of both groups after 12 months (p-value $=0.093$, Effect size $=0.447)$, meanwhile; group 1 was statistically significantly higher than group 2 regarding marginal integrity ( $\mathrm{p}$-value $=0.037$, Effect size $=0.513$ ). Regarding patient satisfaction FRCP and core group showed statistical significant higher satisfaction than endocrown group (p-value $=0.047$, Effect size $=0.447$ ). Conclusion: E.max press endocrowns revealed successful performance similar to e.max press crowns retained with FRCP in terms of gross fracture, however better marginal adaptation and patient satisfaction was obtained with e.max press crowns retained with FRC post and core group.
\end{abstract}

\section{KEYWORDS}

Anterior teeth; Endocrown; Endodontically treated teeth; Fiber Post; E.max.

\section{RESUMO}

Objetivo: O objetivo deste estudo foi avaliar a satisfação do paciente, grau de fratura grosseira e adaptação marginal de endocrowns e.max versus coroas de e.max retidas com pino de compósito reforçado com fibra (FRCP) e núcleo nos dentes anteriores superiores. Material e métodos: $\mathrm{O}$ presente estudo incluiu 24 pacientes que buscavam tratamento endodôntico na arcada superior anterior. Os pacientes receberam tratamento de canal radicular (RCT) e foram divididos aleatoriamente em dois grupos $(\mathrm{n}=12)$. $O$ primeiro grupo recebeu preparação para as coroas IPS e.max retidas com FRCP e núcleo e o segundo grupo recebeu preparos para as endocrowns IPS e.max. A técnica de prensagem foi usada para a fabricação de ambas as restaurações usando os lingotes de prensagem IPS e.max. A integridade marginal e a fratura macroscópica foram avaliadas usando os critérios da USPHS e um questionário foi realizado para avaliar a satisfação do paciente. Os dados foram analisados usando IBM SPSS Statistics for Windows, versão 23.0. Armonk, NY: IBM Corp. Resultados: Não houve diferença estatisticamente significativa em relação à fratura bruta de ambos os grupos após 12 meses (p-valor $=0,093$, tamanho do efeito $=0,447$ ), entretanto; o grupo 1 foi estatisticamente significativamente maior do que o grupo 2 em relação à integridade marginal (p-valor = $0,037$, tamanho do efeito $=0,513)$. Em relação à satisfação do paciente, o FRCP e o grupo principal mostraram maior satisfação estatisticamente significativa do que o grupo endocrown (p-valor $=0,047$, tamanho do efeito $=0,447$ ). Conclusão: as endocrowns E.max press revelaram um desempenho bem-sucedido semelhante às coroas e.max press retidas com FRCP em termos de fratura bruta, no entanto, melhor adaptação marginal e satisfação do paciente foram obtidas com as coroas e.max press retidas com pilar FRC e núcleo de preenchimento.

\section{PALAVRAS-CHAVE}

Dentes anteriores; Endocrown; Dentes tratados endodonticamente; Pino de fibra; E.max. 


\section{INTRODUCTION}

$\mathrm{R}$ estoring endodontically treated teeth (ETT) continues to be a challenge in reconstructive dentistry. Although root canal treatment (RCT) has reached high success rates there is still a great percentage of ETT that must be extracted due to poor coronal restorations [1]. The loss of water and collagen cross-linking after RCT make ETT more brittle, due to structural change in the dentin. opposite to common belief there is no difference in moisture content between vital teeth and ETT, many studies now support the hypothesis that loss of structural integrity associated with the access preparation results in increased cuspal deflection during function, which leads to a higher occurrence of fractures. Considering that in most ETT there are lost tooth structure caused by existing restorations or caries associated to endodontic access preparation $[2,3]$.

For decades post and core system have been used as a foundational material to support the final restoration of ETT with extensive loss of tooth structure, especially FRCP and core system with its excellent flexural and fatigue strength, esthetic properties, modulus of elasticity similar to that of dentin, being easy to handle allow one-visit therapy, biocompatibility, relatively cheap and if necessary can be easily removed, nowadays they are often first clinician choice [4].

However, there are challenges related to the use of FRCP and core system these challenges include; when the post space is too wide in the coronal aspect of the ETT, the cemented post may only contact the tooth in the most apical portion of the post space. Under these conditions, post retention depends primarily upon the cement. In the presence of minimal or no ferrule, when the tooth is subjected to occlusal forces, the cement seal will eventually break, leading to leakage, caries, loss of post retention, and subsequently crown failure. Moreover in ovoid canals (e.g., canines), the post preparation using a matching drill for the post may result in excessive removal of tooth structure, or the post will only contact the root canal space laterally and this may have a weakening effect increasing root fracture chances and now the consensus is the need to conserve remaining healthy dental tissues that can mechanically stabilize the tooth - restoration complex and increase available surface area for adhesion $[5,6]$. Furthermore, elastic fiber posts may cause leakage by allowing the restorations to move and compromise the luting cement which may lead to fracture of the restoration, secondary caries or root canal infection. Findings of clinical studies may confirm this in-vitro data that bond strength between the fiber posts and resin cement is the most frequent failure reason $[7,8]$. Limitations on the use of post \& core including root anatomical variations, dilaceration or short roots, small diameter root shapes and with the improvement of adhesive dentistry, a paradigm shift to post-less approaches in restoring ETT with ferrule is in progress It is now possible to build-up damaged ETT with intra-coronal restorations as endocrowns. Adhesion ensures sufficient material retention without the use of aggressive macro-retentive technique $[9,10]$.

Pissis et al. in 1995 published the first study on endocrowns [11]. They described the ceramic monoblock technique for teeth with extensive loss of coronal tooth structure. However, it was Bindl and Mormann in 1999 who named this restorative procedure "endocrown" [12]. Endocrowns was first indicated for molars especially in cases of obliterated, short, fragile or dilacerated roots. They are also indicated in cases of limited interocclusal space and excessive loss of coronal dental tissue, in which it is impossible to gain enough thickness on the ceramic covering on the metal or ceramic substructure [9]. These crowns would be anchored to the internal portion of the pulp chamber and on the cavity margins, thus obtaining macro-mechanical retention provided by the pulp chamber and micromechanical retention obtained by adhesive cementation [13].

Initially, endocrowns were fabricated from alumina or spinell reinforced non silica-based ceramics and silica-based feldspar ceramics, 
using either a heat-pressed technique or later CAD/CAM technology.

Later, glass ceramics were the material of choice as they provide the advantage of surface modification, either with the use of hydrofluoric acid or air-abrasion, improving in that way their adhesion to the tooth tissues [12]. According to the literature, reinforced glass ceramics with either leucite or lithium disilicate have been considered the best option for the fabrication of endocrowns, since they have high flexural strength than resin composites and feldspathic glass ceramics, and their ability to withstand the occlusal forces during mastication [14,15].

Provision of an endocrown is a relatively easy, cost effective procedure that requires less chairside time in comparison to other indirect restorative alternatives that may require RCT, supragingival margins facilitate clinical inspection and plaque control [16]. Another advantage of the endocrowns is that the number of stages, resulting from using different materials such as cement, post, core and crown, are reduced. It has also been reported in the literature that the stresses which are accumulated at the interfaces of the different materials with different elastic moduli may cause increased root fracture risk, which is also reduced in endocrown restorations $[17,18]$. Nevertheless, endocrown is contraindicated in cases with a short and narrow pulp chamber, if adhesion is not certain and if there is a very little tooth structure remaining [19].

Owing to endocrowns advantages, high success rate in restoring posterior ETT, their aesthetic appeal and the fact that maximal tissue conservation involved with minimally invasive preparation, are now considered 'the gold standard' for restoring posterior ETT, that may make it possible to apply such a prosthetic option in restoring anterior ETT $[18,20]$. Unfortunately, incisors biomechanics differ from molars. Incisors crowns are taller $(10.5 \mathrm{~mm})$ and narrower $(7 \mathrm{~mm})$ than molars $(7.5 \mathrm{~mm}$ length of crown, $10.0 \mathrm{~mm}$ bucco-lingual diameter at the cervix). In accordance with equilibrium of a lever, the bending moments on the restorations in incisors are higher than those acting on molars. In addition, the bonding surface of endocrowns in anterior teeth is an average of 30 $\mathrm{mm} 2$ and is two times smaller than in molars 60 $\mathrm{mm} 2$, which negatively affects the retention of these restorations [21].

Achieving adequate marginal adaptation, high fracture resistance and good esthetic is not easy especially with the continuous innovations of dental ceramic. Furthermore, satisfaction of the patient with final restoration is not always in agreement with the dentist [20].

So, the aim of the present study was to evaluate patient satisfaction, gross fracture and the marginal adaptation of e.max press endocrowns versus e.max press crowns retained with FRCP and core system in upper anterior teeth.

The null hypothesis of this study was that there would be no significant difference between IPS e.max press endocrowns and IPS e.max press crowns retained with FRCP and core system in terms of gross fracture, patient satisfaction and marginal integrity.

\section{METHODS}

\section{Ethical considerations and approval}

This study was approved by the Research Ethics Committee of the Faculty of Dentistry, Cairo university, Cairo, Egypt (approval no: 17113). Written informed consent regarding treatment sequence, publishing of their images and results was obtained from all participants.

\section{Registration:}

This trial was registered at the Clinical Trials.gov registry under registration number NCT03331887 on November 7, 2017.

\section{Study design}

This study was a double blind randomized controlled clinical trial with a 1:1 allocation ratio. 


\section{Participants:}

All participants fulfilled the following inclusion criteria, age range from 20-50 years old with healthy physical status and able to read and write, good oral hygiene and motivation, no active periodontal or apical lesions, having upper anterior teeth indicated for RCT and with at least $2-3 \mathrm{~mm}$ of tooth structure above cementenamel junction, normal occlusal relation and casts that could be assembled for bite registration were recruited during the time from July 2018 till September 2018 from the outpatient clinic of Fixed Prosthodontics Department, Faculty of Dentistry, Cairo University, Cairo, Egypt. Screenings of patients were carried out until target number was reached. This study was completed by November 2019. Full medical and dental history were obtained from all participants.

\section{Sample size:}

A total of 24 restorations (12 in each group) was sufficient with $80 \%$ power and at $5 \%$ significance. Sample size calculation was achieved using PS: Power and Sample Size Calculation Software Version 3.1.2 (Vanderbilt University, Nashville, Tennessee, USA) [22].

\section{Allocation concealments}

In each group number for each member was written by indispensable pen on large white paper sheet. The sheet was folded eight times and saved inside opaque well sealed envelope.

\section{Implementation}

The candidate under supervision was responsible for providing allocation generation and dividing patients into two groups and save it in the envelopes in secured place until the date of performing procedure.

\section{Randomization}

Randomization was carried out using computerized sequence generation (https:// www.randomizer.org/) in the Center of Evidence Based Dentistry, Cairo University.
Participants were assigned in two groups (A and $\mathrm{B}$ ) according to the type of preparation received. Each participant received a sealed opaque envelope with their randomized number. Group A received preparation for the IPS e.max crowns retained with FRCP and core and group $B$ received preparation for the IPS e.max endocrowns.

Table I - Sample grouping

\begin{tabular}{|ccc|}
\hline $\begin{array}{c}\text { Group (A) } \\
\text { Control group }\end{array}$ & $\begin{array}{c}\text { Group (B) } \\
\text { Intervention group }\end{array}$ & $\begin{array}{c}\text { Total number of } \\
\text { restorations }\end{array}$ \\
\hline $\begin{array}{c}\text { E.max press crowns } \\
\text { Retained with FRCP } \\
(n=12)\end{array}$ & $\begin{array}{c}\text { Emax press Endocrowns. } \\
(n=12)\end{array}$ & $(n=24)$ \\
\hline
\end{tabular}

\section{Blinding}

The trial participants and outcome assessors (a prosthodontist college) were blinded throughout the whole procedures (double blind). The dentist practitioner was responsible for all clinical procedures.

\section{Intervention:}

Two different restorations (e.max press crowns retained with FRCP and core system and e.max press endocrowns) were selected for this study. All treatment procedures were performed by the same clinician.

The prosthodontics procedures were performed into 5 visits in the clinics of fixed prosthodontics department, faculty of dentistry, Cairo university, Cairo, Egypt.

\section{Visit 1}

Intra-oral and extra-oral examination were performed. A set of at least 12 pictures were taken for each participant. Scaling and polishing were performed for each patient before shade selection. The color of the tooth was recorded digitally with Vita Easy shade V spectrophotometer $^{1}$. An alginate impression ${ }^{2}$ for upper and lower arches were taken to pour a diagnostic cast so that a silicone putty index ${ }^{3}$

\footnotetext{
${ }^{1}$ VITA, Zahnfabrik, Germany.

${ }^{2}$ CA 37, Cavex, Haarlem, The Netherlands.

${ }^{3}$ Zhermack, Elite® HD+ Putty soft, fast set, Italy.
} 
for a provisional restoration was made, involving at least one tooth beyond the tooth to be restored, if the tooth was broken down, adjustments with inlay wax were done before the index was taken.

\section{Visit 2}

RCT was done using rotary system NiTi Protaper ${ }^{4}[23,24]$ and obturation was done using lateral condensation technique after gutta-percha point were coated with $\mathrm{AH}$ Plus $^{5}$ resin sealer [25]. A confirmatory periapical $\mathrm{x}$-ray was taken, then excess gutta-percha was removed till the level of the canal orifice. Access cavities were blocked using flowable composite Filtek $\mathrm{Z}_{350^{6}}$ then at least 3 days were left before starting preparation for both groups [26].

\section{Visit 3}

A)

For FRC post and core preparation (Group

\section{Ferrule preparation}

Weak, undermined coronal tissue and spurs of tissue, which was less than $2 \mathrm{~mm}$, was reduced and the remaining, well-supported tissue was beveled. Ferrule preparation was done by extension of the axial wall of the crown 1.5- $2 \mathrm{~mm}$ apical to the missing tooth structure and checked by periodontal probe ${ }^{7}$ [27].

\section{Post space preparation}

Gutta percha was removed using gates glidden drills ${ }^{8}$ size 2 and 3, with rubber stopper adjusted at the intended length leaving 3-5 mm apical seal. Then root canal was widened and enlarged with the drill ${ }^{9}$ corresponding to the post diameter and drilling length was guided by the rubber stopper.

\section{Fiber post cementation}

Before cementation the root canal was irrigated with normal saline and then was gently

\footnotetext{
${ }^{4}$ Dentsply, Switzerland.

${ }^{5}$ DENTSPLY, GERMANY.

${ }^{6}$ 3MESPE Dental products, St. Paul, USA.

${ }^{7}$ NORDENTt, INC.

${ }^{8}$ NORDIN SWISS DENTAL PRODUCTS.

9 Pentron Clinical Technologies LLC, Wallingford, Connecticut, United States.
}

dried with paper points. All steps of cementation were done according to manufacturer instructions using Biscem self-adhesive resin cement $^{10}$. After cement application the Fibre Kleer post ${ }^{11}$ were inserted in the canal, all excess cement was removed and then light curing ${ }^{12}$ of the occlusal surface for $20 \mathrm{sec}$ (Figure 1).

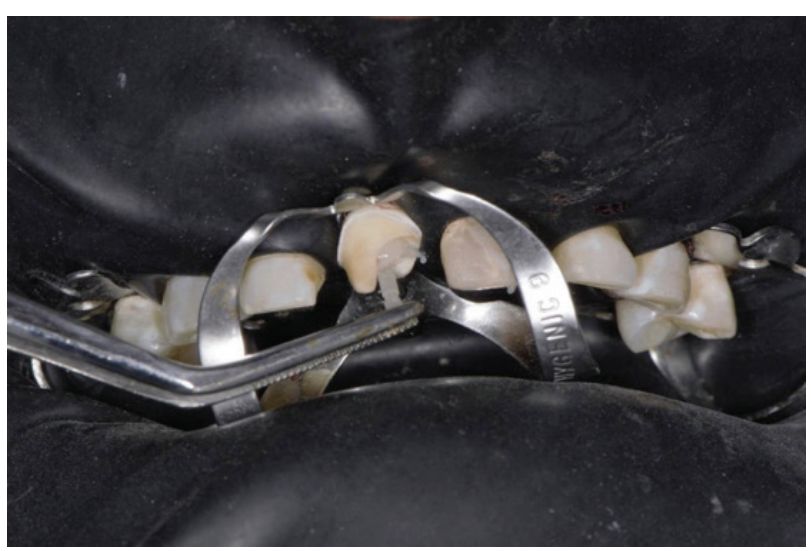

Figure 1 - Fiber post cementation.

Core build up and extra-coronal preparation

Dentin bonding agent all bond universal ${ }^{13}$ was applied on the tooth structure, then buildup of the core was done using Build-It $\mathrm{TM}^{14}$ core material. Preparation of teeth for full coverage restoration were performed with smooth, round contours and line-angles, Chamfer finish lines of $1 \mathrm{~mm}$ in diameter with round internal angles, and incisal reduction of $2 \mathrm{~mm}$. (Figures 2)

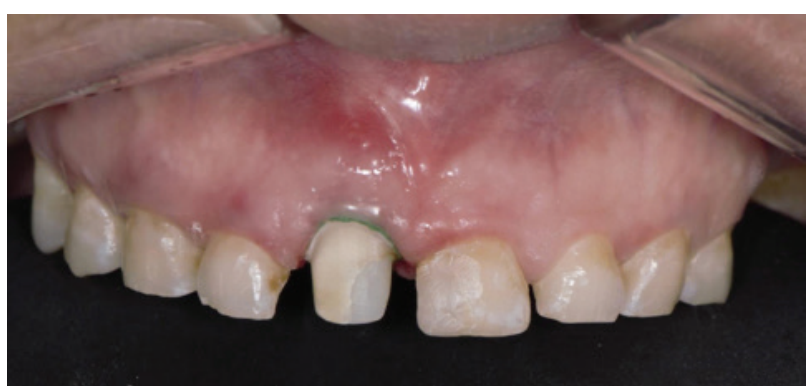

Figure 2 - Extra-coronal preparation after core build up.

\footnotetext{
${ }^{10}$ Bisco, United States.

${ }^{11}$ Pentron Clinical Technologies LLC, Wallingford, Connecticut, United States.

${ }^{12}$ ULTRADENT PRODUCTS, INC.

${ }^{13}$ Bisco, United States.

${ }^{14}$ Pentron Clinical Technologies LLC, Wallingford, Connecticut, United States.
} 


\section{For endocrown preparation: (Group B)}

The pulp chamber was prepared to eliminate undercuts with a $10^{\circ}$ coronal divergence using tapered round diamond stone and a depth of 4-5 $\mathrm{mm}$ from the cavo-surface margin checked with periodontal probe [5]. (Figure 3)

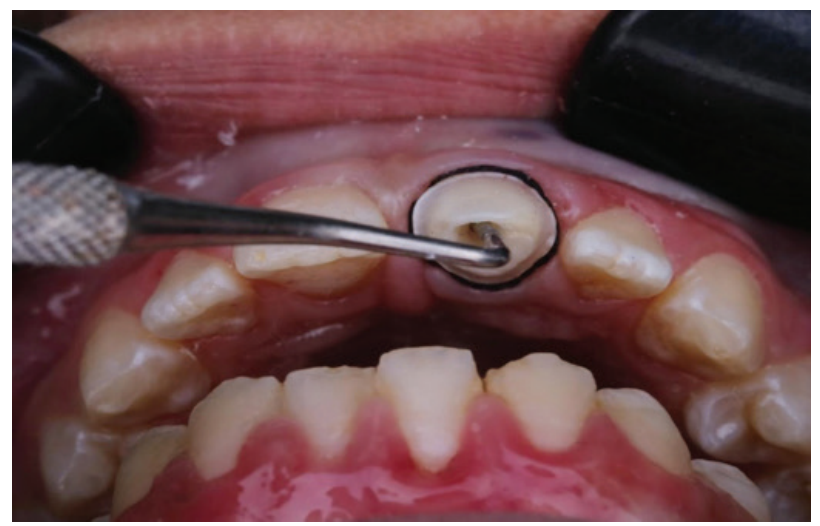

Figure 3 - Pulp chamber preparation depth checking by periodontal probe.

The internal line angles were rounded and smoothened using tapered with round finishing stones. Each preparation was verified vertically with the silicone index to check the amount of reduction.

Extra-coronal preparation followed the same principles and steps done for teeth prepared to receive the IPS e.max press crowns of group A. (Figure 4)

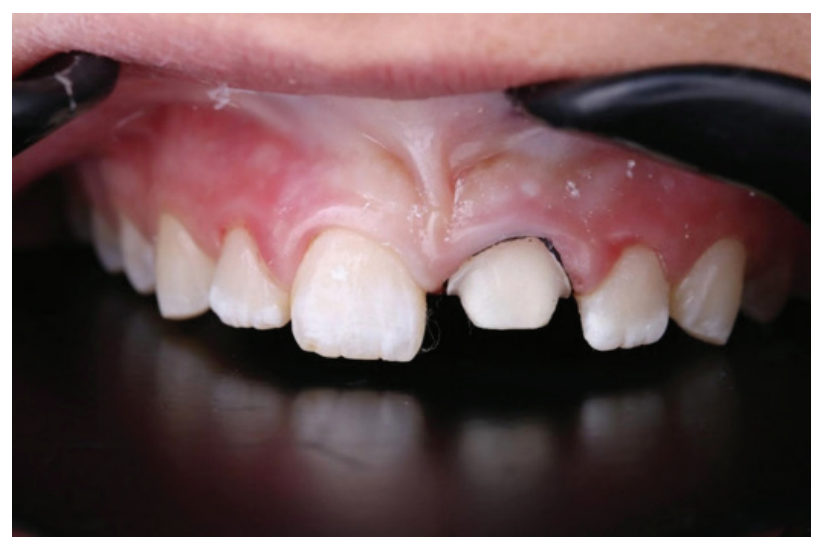

Figure 4 - Finishing of endocrown preparation.
Vinyl polysiloxane elastomeric impressions $^{15}$ were made using two steps (putty-wash) impression technique: in the first step, the putty impression was taken before tooth preparation, then the excess material was removed and escape channels were cut in the putty impression using dental scalpel and scalpel ${ }^{16}$ blade size $11^{17}$. The second step was taken after preparation by relining the putty impression with light wash ${ }^{18}[28]$.

Provisional restoration was constructed using the direct technique by injecting provisional restorative material ${ }^{19}$ in the tissue surface of the putty index then seating it on the prepared tooth, after lubricating it and the adjacent gingival margin with petroleum jelly, with up and down movement before removing the index until it set [5]. After finishing and polishing of the provisional restorations ${ }^{20}$, they were cemented with non-eugenol provisional cement $^{21}$ [29].

\section{Laboratory construction procedures}

Pressing technique was used for the fabrication of all restorations using IPS e.max press Ingots $\mathrm{LT}^{22}$. Wax pattern was designed by $\mathrm{CAD} / \mathrm{CAM}^{23}$ use biogeneric individual mode with standard die spacer $50 \mu \mathrm{m}$ then wax pattern was milled ${ }^{24}$ from a wax disc $14 \mathrm{~mm}^{25}$ using three milling burs ( $2 \mathrm{~mm}, 1 \mathrm{~mm}, 0.5 \mathrm{~mm}$ ).

\section{Trial fit of the restorations}

After pressing, divesting was performed then, trial fit of the restorations was performed on their corresponding dies on the articulator to check appropriateness of the overall anatomic form in relation to the adjacent teeth and arch, the adequacy of the proximal contacts, the quality of the crown margins, occlusion and

\footnotetext{
${ }^{15}$ Honigum impression material, DMG, Germany.

${ }^{16}$ International (HK) Co, Jiangsu, China.

${ }^{17}$ Huaian Ruijie medical instruments Co., Ltd. Jiangsu, China.

${ }^{18}$ Zhermack, Elite ${ }^{\circledR}$ HD+ Light body, fast set, Italy.

${ }^{19} 3 \mathrm{M}$, Protemp ${ }^{\mathrm{TM}}$ Plus temporization material shade A2 refill, USA.

${ }^{20}$ Pentron Clinical Technologies, United States.

${ }^{21}$ RelyX Temp NE, 3MESPE, USA.

${ }^{22}$ Ivoclar Vivadent, Zürich, Switzerland.

${ }^{23}$ IN LAB 18.1 CAM, Sirona

${ }^{24}$ InLab MC X5 milling machine, Sirona

${ }^{25}$ Kuraray Noritake Dental Inc America, Inc.
} 
articulation. Any needed adjustments were carried out then the outer side of the restoration was cleaned by blasting with type $100 \mathrm{Al}_{2} \mathrm{O}_{3}$ at 1 bar (15 psi) pressure and then cleaned with the steam cleaner.

Following the complete adjustments of the restorations, the restorations were glazed using IPS e.max fluorescent glaze paste ${ }^{26}$ and lithium disilicate stains ${ }^{27}$ were applied whenever necessary.

\section{Intra-oral trial fit of the restorations}

a - The temporary crowns were carefully removed and all temporary cement fragments thoroughly cleaned from the tooth using hand instruments;

$\mathrm{b}$ - With the patient in a semi-supine position the restorations were placed on the tooth and the position was maintained with a finger placed on the occlusal surface, the fit of the restorations margin was first assessed using the tip of an explorer around the total margin periphery, ensuring that the restorations remained completely seated on the tooth. There should be a relatively smooth transition from the restoration to tooth with no visible restoration opening, overhang or other discrepancy. If the margin appeared to be open along or any catch with the tip of the explorer occurred, rechecking of the restoration complete seating was first done then remnants of temporary cement or other debris on the tooth surface or trapped in the gingiva or on the internal surface of the crown were also checked;

c - Internal fit and tightness of the proximal contact were located using pressure indicating paste $^{28}$. The internal surface is coated and the crown seated then removed for checking any binding areas. Areas where the ceramic showed through the coating were adjusted to allow accurate seating. If contacts and internal surface after adjustment were satisfactory, occlusion was then checked using Shimstock Film - 12 microns ${ }^{29}$, then polishing of the restorations were

\footnotetext{
${ }^{26}$ Ivoclar ivadent, Zürich, Switzerland

${ }^{27}$ IPS E-max ceram shades, Ivoclar Vivadent, Zürich, Switzerland

${ }^{28}$ Keystone industries Stockholzstr, Germany

${ }^{29}$ Bausch, Australasia, Pty. Ltd
}

performed using e.max polishing $\mathrm{kit}^{30}$ but if an open margin persists that cannot be overcome, a new impression were necessary for fabrication of a new restoration.

\section{Cementation of the restorations}

a - Rubber dam was applied to the tooth for isolation, then $5 \%$ hydrofluoric acid ${ }^{31}$ was applied for $20 \mathrm{sec}$ then rinsed with copious amount of water for $60 \mathrm{sec}$ and followed by air drying for 30 sec with moisture-free air.

b - Bis-Silane ${ }^{32}$ was applied for $60 \mathrm{sec}$ and allowed to dry.

\section{Clinical evaluation}

Recall examinations were performed to all patients after 3, 6, 9, and 12 months. During the examination, direct clinical evaluation was performed using modified USPHS criteria [30] for marginal integrity and gross fracture and a questionnaire [31, 32] were used to evaluate patients' satisfaction and potential postoperative discomfort in the form of questions. (Table II)

Table II - The different outcomes and their measuring device and measuring unit

\begin{tabular}{|c|c|c|c|}
\hline & $\begin{array}{l}\text { Outcome } \\
\text { name }\end{array}$ & $\begin{array}{l}\text { Measuring } \\
\text { device }\end{array}$ & Measuring Unit \\
\hline Primary $1^{\mathrm{ry}}$ & Gross Fracture & $\begin{array}{l}\text { Modified Ryge } \\
\text { Criteria }\end{array}$ & $\begin{array}{c}\text { Categorical } \\
\text { Alpha (A): Restoration is intact } \\
\text { and fully retained. } \\
\text { Bravo (B): Restoration is partially } \\
\text { retained with some portion of the } \\
\text { restoration still intact. } \\
\text { Charlie (C): Restoration is com- } \\
\text { pletely missing }\end{array}$ \\
\hline $\begin{array}{l}\text { Secondary } \\
2^{2^{y}}\end{array}$ & $\begin{array}{l}\text { Patient satis- } \\
\text { faction }\end{array}$ & $\begin{array}{l}\text { Visual Analogue } \\
\text { Scale(VAS) }\end{array}$ & Score \\
\hline $\begin{array}{l}\text { Secondary } \\
2^{r y}\end{array}$ & $\begin{array}{l}\text { Marginal Inte- } \\
\text { grity }\end{array}$ & $\begin{array}{l}\text { Modified Ryge } \\
\text { Criteria }\end{array}$ & $\begin{array}{l}\text { Categorical } \\
\text { Alpha (A): The explorer does not } \\
\text { catch and no visible crevice along } \\
\text { the periphery of the restoration. } \\
\text { Bravo (B): The explorer catches } \\
\text { indicating that the edge of the } \\
\text { restoration does not adapt closely } \\
\text { to the tooth structure. The dentin } \\
\text { and/or the base is not exposed, } \\
\text { and the restoration is not mobile. } \\
\text { Charlie } \odot \text { : The explorer penetra- } \\
\text { tes and extended to the dento-e- } \\
\text { namel junction. }\end{array}$ \\
\hline $\begin{array}{l}{ }^{0} \text { Ivoclar } \\
{ }^{1} \text { Bisco, } \\
{ }^{2} \text { Bisco, }\end{array}$ & $\begin{array}{l}\text { dent, Zürich } \\
\text { ed States. } \\
\text { ed States. }\end{array}$ & Switzerla & \\
\hline
\end{tabular}




\section{Statistical analysis}

Qualitative data were presented as frequencies and percentages. Chi-square or Fisher's Exact test were used to compare between qualitative variables in the two groups. Friedman's test was used to study the changes by time within each group. Kaplan-Meier survival curve was constructed to calculate the mean survival estimates of the two groups. Comparison between survival times was performed using Log rank test. The significance level was set at $\mathrm{p} \leq 0.05$. Statistical analysis was performed with IBM SPSS Statistics for Windows, Version 23.0. Armonk, NY: IBM Corp.

\section{RESULTS}

\section{Gross Fracture}

Results of comparison between the two groups are presented in Table (III). After 3 months; all restorations in the two groups showed (Alpha) score. After 6, 9 as well as 12 months; there was no statistically significant difference between the two groups (p-value $=1.000$, Effect size $=0.209),(\mathrm{p}$-value $=0.217$, Effect size $=$ $0.378)$ and (p-value $=0.093$, Effect size $=0.447$ ), respectively. As regards the changes by time within Fiber post and crown group; there was no change in fracture scores through the study period. While in Endocrown group, there was a statistically significant change in fracture scores through the study period ( $\mathrm{p}$-value $=0.027$, Effect size $=$ 0.255). There was an increase in prevalence of Bravo scores after 6 months. From 6 to 9 months; there was an increase in prevalence of Bravo and Charlie scores. From 9 to 12 months, there was a decrease in prevalence of Bravo scores and an increase in prevalence of Charlie scores.
Table III - Frequencies (n), percentages (\%) and results of Fisher's Exact test for comparison between gross fracture scores of Fiber post and crown and Endocrown groups

\begin{tabular}{|c|c|c|c|c|c|c|}
\hline \multirow[t]{2}{*}{ Time } & \multicolumn{2}{|c|}{$\begin{array}{l}\text { Fiber post and } \\
\text { crown } \\
(n=12)\end{array}$} & \multicolumn{2}{|c|}{$\begin{array}{l}\text { Endocrown } \\
\qquad(n=12)\end{array}$} & \multirow[t]{2}{*}{$P$-value } & \multirow{2}{*}{$\begin{array}{c}\text { Effect size } \\
\text { (v) }\end{array}$} \\
\hline & n & $\%$ & $\mathbf{N}$ & $\%$ & & \\
\hline $\begin{array}{l}3 \text { months } \\
\text { Alpha }\end{array}$ & 12 & 100 & 12 & 100 & \multicolumn{2}{|c|}{ Not computed } \\
\hline \multicolumn{7}{|l|}{6 months } \\
\hline Alpha & 12 & 100 & 11 & 91.7 & \multirow{3}{*}{1.000} & \multirow{3}{*}{0.209} \\
\hline Bravo & 0 & 0 & 1 & 8.3 & & \\
\hline Charlie & 0 & 0 & 0 & 0 & & \\
\hline \multicolumn{7}{|l|}{9 months } \\
\hline Alpha & 12 & 100 & 9 & 75 & \multirow{3}{*}{0.217} & \multirow{3}{*}{0.378} \\
\hline Bravo & 0 & 0 & 2 & 16.7 & & \\
\hline Charlie & 0 & 0 & 1 & 8.3 & & \\
\hline \multicolumn{7}{|l|}{12 months } \\
\hline Alpha & 12 & 100 & 8 & 66.7 & \multirow{3}{*}{0.093} & \multirow{3}{*}{0.447} \\
\hline Bravo & 0 & 0 & 0 & 0 & & \\
\hline Charlie & 0 & 0 & 4 & 33.3 & & \\
\hline
\end{tabular}

${ }^{*}$ : Significant at $p \leq 0.05$

\section{Marginal integrity}

Results of comparison between the two groups are presented in Table (IV). After 3 months; all restorations in the two groups showed (Alpha) score. After 6 as well as 9 months; there was no statistically significant difference between the two groups (P-value $=1.000$, Effect size $=0.209)$ and ( $\mathrm{p}$-value $=0.093$, Effect size $=$ 0.447), respectively. After 12 months; there was a statistically significant difference between the two groups (P-value $=0.037$, Effect size $=0.513$ ). Fiber post and crown group showed statistically significantly lower prevalence of Bravo score and fractures crowns than Endocrown group. In Fiber post and crown group; there was no change in the scores so no statistical comparison was performed. In Endocrown group; there was a statistically significant change in marginal integrity scores through the study period (p-value $=0.007$, Effect size $=0.333$ ). There was an increase in prevalence of Charlie score and an increase in fractured crowns after 6 and 9 months. 
Table IV - Descriptive statistics and results of Fisher's Exact test for comparison between marginal integrity scores in Fiber post and crown and Endocrown groups

\begin{tabular}{|c|c|c|c|c|c|c|}
\hline \multirow[t]{2}{*}{ Time } & \multicolumn{2}{|c|}{$\begin{array}{l}\text { Fiber post and } \\
\text { crown } \\
(n=12)\end{array}$} & \multicolumn{2}{|c|}{$\begin{array}{l}\text { Endocrown } \\
\quad(n=12)\end{array}$} & \multirow[t]{2}{*}{$P$-value } & \multirow[t]{2}{*}{$\begin{array}{c}\text { Effect size } \\
\text { (v) }\end{array}$} \\
\hline & $\mathbf{n}$ & $\%$ & $\mathbf{N}$ & $\%$ & & \\
\hline $\begin{array}{l}3 \text { months } \\
\text { Alpha }\end{array}$ & 12 & 100 & 12 & 100 & \multicolumn{2}{|c|}{ Not computed } \\
\hline \multicolumn{7}{|l|}{6 months } \\
\hline Alpha & 12 & 100 & 11 & 91.7 & \multirow{4}{*}{1.000} & \multirow{4}{*}{0.209} \\
\hline Bravo & 0 & 0 & 1 & 8.3 & & \\
\hline Charlie & 0 & 0 & 0 & 0 & & \\
\hline Fracture & 0 & 0 & 0 & 0 & & \\
\hline \multicolumn{7}{|l|}{9 months } \\
\hline Alpha & 12 & 100 & 9 & 75 & \multirow{4}{*}{0.093} & \multirow{4}{*}{0.447} \\
\hline Bravo & 0 & 0 & 2 & 16.7 & & \\
\hline Charlie & 0 & 0 & 1 & 8.3 & & \\
\hline Fracture & 0 & 0 & 1 & 8.3 & & \\
\hline \multicolumn{7}{|l|}{12 months } \\
\hline Alpha & 12 & 100 & 8 & 66.7 & \multirow{4}{*}{$0.037^{\star}$} & \multirow{4}{*}{0.513} \\
\hline Bravo & 0 & 0 & 0 & 0 & & \\
\hline Charlie & 0 & 0 & 4 & 33.3 & & \\
\hline Fracture & 0 & 0 & 4 & 33.3 & & \\
\hline
\end{tabular}

*: Significant at $p \leq 0.05$

\section{Patient satisfaction}

After 3 months; all patients in the two groups were satisfied. After 6 months; 100\% of patients in Fiber post and crown group were satisfied. In Endocrown group; 91.7\% of patients were satisfied and $8.3 \%$ were dissatisfied. There was no statistically significant difference between the two groups after 6 months (p-value $=1.000$, Effect size $=0.209$ ). After 9 months; $100 \%$ of patients in Fiber post and crown group were satisfied. In Endocrown group; 75\% of patients were satisfied and 25\% were dissatisfied. There was no statistically significant difference between the two groups after 9 months (p-value $=0.217$, Effect size $=0.378$ ). After 12 months; $100 \%$ of patients in Fiber post and crown group were satisfied. In Endocrown group; $66.7 \%$ of patients were satisfied and $33.3 \%$ were dissatisfied. There was a statistically significant difference between the two groups after 12 months ( $\mathrm{p}$-value $=0.047$, Effect size $=0.447)$. Fiber post and crown group showed statistically significantly higher satisfaction than Endocrown group. In Fiber post and crown group; there was no change in satisfaction scores so no statistical comparison was performed. In Endocrown group; there was no statistically significant change in patient satisfaction through the study period ( $\mathrm{p}$-value $=0.058$, Effect size $=$ 0.208). (Figure 6)

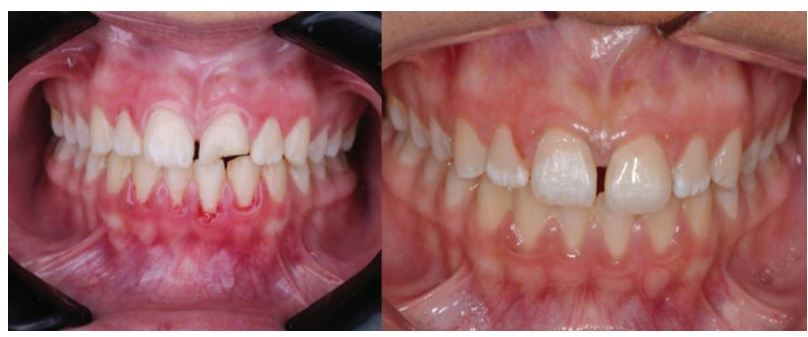

Figure 5 - Pre and Post-operative photo for an endocrowns case.

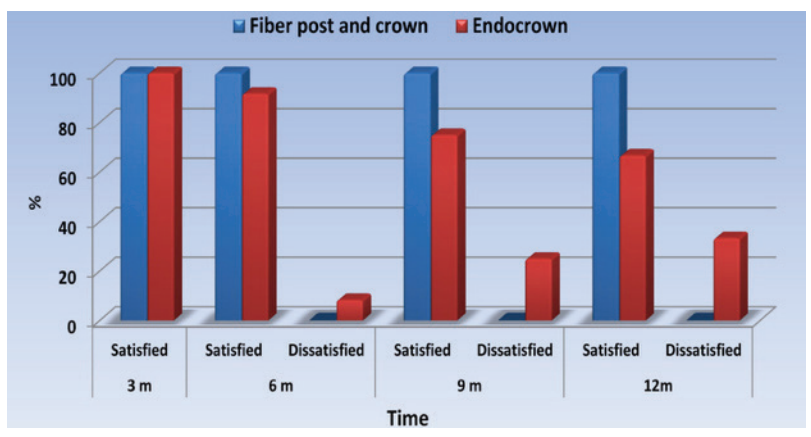

Figure 6 - Bar chart representing patient satisfaction scores in Fiber post and crown and Endocrown groups.

\section{DISCUSSION}

The first null hypothesis regarding gross fracture was accepted since IPS e.max press endocrowns and IPS e.max press crowns retained with FRCP and core revealed comparable clinical and statistical results, while the second and third null hypothesis were rejected, since IPS e.max press endocrowns revealed lower marginal integrity and patient satisfaction than IPS e.max press crowns retained with FRCP and core system.

Concerning marginal integrity results, no statistical significant difference was found between the two groups at 3, 6 and 9 months, while at 12 months there was a statistical significant difference 
between them as the FRCP group showed better results. In crown retained with FRCP and core group; there was no change in the scores so no statistical comparison was obtained. In Endocrown group; there was a statistically significant change in marginal integrity scores through the study period ( $\mathrm{p}$-value $=0.007$, Effect size $=0.333$ ). There was an increase in prevalence of Charlie score after 6 and 9 months. There was an increase in prevalence of gross fractured crowns after 9 and 12 months.

This result may be contributed to the extension of the anterior endocrowns restoration in the pulp chamber [33]. Gaintantzopoulou et al. 2015 [34] reported that increasing the intraradicular extension of endocrown restorations increased the marginal and internal gap of restorations and Soliman et al. 2019 [35] also reported that minimal marginal gaps associated with shallow depth can be attributed to the better seating of the shallow endocrown compared to deeper prepared cavities thus minimizing the vertical marginal gaps. This finding was in accordance with Forberger and Gohring et al. 2008 [36] who reported that endocrowns showed significantly less marginal integrity compared to crowns retained post and cores.

Concerning gross fracture results, no statistical significant difference was found between the two groups at 3, 6, 9 and 12 months. This finding is clinically relevant because it revealed that endocrowns may show comparable clinical performance to restorations made with intra-radicular posts. This was in accordance to Ramírez-Sebastià et al. 2013 [37] who reported that the use of endocrowns or a short glass fiber post with an adhesive crown is sufficient for the restoration of largely destroyed anterior teeth provided with a ferrule effect of at least $2 \mathrm{~mm}$. Another interpretation to such finding may be due to the amount of remaining ferrule that seems to be a predominant factor for tooth survival in extensively structurally compromised non-vital teeth [38].

Although there was no statistically significant difference between the two groups; after 12 months, 33.3\% showed (Charlie) score in endocrown group. This may be attributed to adhesion failure and to the fact that those endocrowns showed marginal discrepancy which might have led to gross fracture. This was in accordance with Halawani et al. 2017 who stated that a good marginal fit seems to be one of the most important technical factors for the long-term success of any restoration and that the intaglio surface of a crown is critical for the retention and resistance of the crown. Having a better-adapted crown will increase the success and longevity of the crown. Variations in adaptation could lead to stress concentration which may in turn reduce the strength of the restoration and consequently cause its debonding and fracture [33]. This finding was in agreement with previous studies with regard to fracture resistance of post-core restorations $[39,40,41]$.

Concerning patient satisfaction result, no statistical significant difference was found between the two groups at 3, 6 and 9 months, while at 12 months $100 \%$ of patients in Fiber post and crown group were satisfied, while $33.3 \%$ in endocrown group were dissatisfied. There was a statistically significant difference between the two groups and this result may be due to marginal discrepancy and debonding of endocrowns that have been noticed at 9 and 12 months follow up period.

\section{Limitations}

More clinical studies are required with prolonged follow-up periods, larger sample size and different materials to evaluate long-term clinical performance of anterior endocrowns along with patient satisfaction in order to be used in different clinical situations for better outcome.

\section{CONCLUSION}

Within the limitations of this study the following could be drawn:

1- E.max press endocrowns revealed successful performance similar to e.max press crowns retained with FRCP in terms of gross fracture, however minute marginal discrepancy was obtained due to e.max press endocrowns; 
2- E.max press crowns retained with FRCP and core system revealed higher patient satisfaction after one year than e.max press endocrowns;

3- Crowns retained with FRCP and core system are still recommended for restoring anterior ETT.

\section{REFERENCES}

1. Papalexopoulos D, Filippatos G. Restoring endodontically treated teeth: from immediate restorations to the. reverse" preparation approach". EC Dent Sci. 2019;18(9):2159-68.

2. Papa J, Cain C, Messer HH. Moisture content of vital vs endodontically treated teeth. Endod Dent Traumatol. 1994;10(2):91-93. doi: 10.1111//.16009657.1994.tb00067.x

3. Sedgley $\mathrm{CM}, \mathrm{Messer} \mathrm{HH}$. Are endodontically treated teeth more brittle? J Endod. 1992 Jul;18(7):332-5. doi:10.1016/S0099-2399(06)80483-8

4. Bonchev A, Radeva E, Tsvetanova N. Fiber reinforced composite posts-a review of literature. Int J Sci Res. 2017;6(10):1887-93.

5. Irmaleny,Zuleika, Ardjanggi S, Mardiyah AA, Wahjuningrum DA. Endocrown restoration on postendodontics treatment on lower first molar. J Int Soc Prev Community Dent. 2019;9(3):303-10. doi:10.4103/jispcd.JISPCD_399_18

6. Sherfudhin H, Hobeich J, Carvalho CA, Aboushelib MN, Sadig W, Salameh Z. Effect of different ferrule designs on the fracture resistance and failure pattern of endodontically treated teeth restored with fiber posts and all-ceramic crowns. J Appl Oral Sci. 2011;19(1):28-33. doi:101590/s167877572011000100007

7. Monticelli F,Grandini S, Goracci C, Ferrari M. Clinical behavior of translucentfiber posts: a 2-year prospective study. Int J Prosthodont. 2003;16(6):593-6.

8. Ferrari M, Cagidiaco MC, Goracci C, Vichi A, Mason PN, Radovic I, et al. Longterm retrospective study of the clinical performance of fiber posts. Am J Dent. 20070ct;20(5):287-91.

9. Ghajghouj 0, Taşar-Faruk S. Evaluation of fracture resistance and microleakage of endocrowns with different intracoronal depths and restorative materials luted with various resin cements. Materials (Basel). 2019 Aug 8;12(16):2528. doi: 10.3390/ma12162528.

10. Kayabasi 0 . Effects of post material and cement on stress distribution by using finite element analysis and in vitro fracture test. J Eng Appl Sci. 2018;7(1):799-810.

11. Pissis P.Fabrication of a metal-free ceramic restoration utilizing the monobloc technique.Pract Periodontics Aesthet Dent. 1995;7(5):83-94

12. Bindl A, Mörmann WH. Clinical evaluation of adhesively placed Cerec endocrowns after 2 years--preliminary results. J Adhes Dent. 1999;1(3):255-65.

13. El Ghoul WA, Özcan M, Ounsi H, Tohme H, Salameh Z. Effect of different CAD-CAM materials on the marginal and internal adaptation of endocrown restorations: An in vitro study. J Prosthet Dent. 2020 Jan;123(1):128-34. doi: 10.1016/j.prosdent.2018.10.024

14. Biacchi GR, Basting RT. Comparison of fracture strength of endocrowns and glass fiber post-retained conventional crowns. Oper Dent. 2012 MarApr;37(2):130-6. doi: 10.2341/11-105-L.

15. Zhu J, Rong Q, Wang X, Gao X. Influence of remaining tooth structure and restorative material type on stress distribution in endodontically treated maxillary premolars: A finite element analysis. JProsthet Dent. 2017 May;117(5):646-55. doi:10.1016/.jprosdent.2016.08.023

16. Biacchi GR, Mello B, Basting RT. The endocrown: an alternative approach for restoring extensively damaged molars. J Esthet Restor Dent. 2013 Dec;25(6):383-90. doi: 10.1111/jerd.12065

17. Assif $D$, Gorfil C. Biomechanical considerations in restoring endodontically treated teeth. J Prosthet Dent. 1994 Jun;71(6):565-7. doi:10.1016/00223913(94)90438-3.

18. Zarone F, Sorrentino R, Apicella D, Valentino B, Ferrari M, Aversa R, etal. Evaluation of the biomechanical behavior of maxillary central incisors restored by means of endocrowns compared to a natural tooth: a 3D static linear finite elements analysis. Dent Mater. 2006 Nov;22(11):1035-44. doi: 10.1016/.j.dental.2005.11.034

19. Elagra ME. Endocrown preparation: Review. J Int Applied Dent Scie. 2019;5(1):253-6.

20. Dietschi D, Duc 0, Krejcil, Sadan A. Biomechanical considerations for the restoration of endodontically treated teeth: a systematic review of the literature, Part II (Evaluation of fatigue behavior, interfaces, and in vivo studies). Quintessence Int. 2008;39(2):117-29.

21. Dejak B, Młotkowski A. Strength comparison of anterior teeth restored with ceramic endocrowns vs custom-made post and cores. J Prosthodont Res. 2018 Apr;62(2):171-6. doi: 10.1016/j.jpor.2017.08.005

22. Otto T,Mörmann WH. Clinical performance of chairside CAD/CAM feldspathic ceramic posterior shoulder crowns and endocrowns up to 12 years. INT J COMPUT DENT. 2015;18(2):147-61.

23. de Alencar AH, Dummer PM, Oliveira HC, Pécora JD, Estrela C. Procedural errors during root canal preparation using rotary NiTi instruments detected by periapical radiography and cone beam computed tomography. Braz Dent J. 2010;21(6):543-9. doi: 10.1590/s0103-64402010000600011

24. Thompson SA. An overview of nickel-titanium alloys used in dentistry. Int Endod J. 2000 Jul;33(4):297-310. doi: 10.1046/.j1365-2591.2000.00339.x

25. Khandelwal D, Ballal NV. Recent advances in root canal sealers. J Int Clin Dent. 2016;9(3):183-94.

26. Nagas E, Karaduman E, Sahin C, Uyanik 0, Canay S. Effect of timing of post space preparation on the apical seal when using different sealers and obturation techniques. J Dent Sci. 2016 Mar;11(1):79-82. doi: 10.1016/j. jds.2012.05.01

27. Carvalho MA, Lazari PC, Gresnigt M, Del Bel Cury AA, Magne P.Current options concerning the endodontically-treated teeth restoration with the adhesive approach. Braz Oral Res. 2018;32(1): e74.

28. Al-Atyaa ZT, Majeed MA. Comparative Evaluation of the Marginal and Internal Fitness of Monolithic CAD/CAM Zirconia Crowns Fabricated from Different Conventional Impression Techniques and Digital Impression Using Silicone Replica Technique (An in vitro study). Biomed Pharmacol J. $2018 \mathrm{Mar}$ 25;11(1):477-90

29. Chiluka L, Shastry YM, Gupta N, Reddy KM, Prashanth NB, Sravanthi K. An In vitro study to evaluate the effect of eugenol-free and eugenol-containing temporary cements on the bond strength of resin cement and considering time as a factor. J Int Soc Prev Community Dent. 2017 Jul-Aug;7(4):202-7. doi: 10.4103/jispcd.JISPCD 13817

30. Ercan E, Dülgergil CT, Soyman M, Dalli M, Yildirim I. A field-trial of two restorative materials used with atraumatic restorative treatment in rural Turkey:24-month results. J Appl Oral Sci. 2009 Jul-Aug;17(4):307-14. doi: 10.1590/s1678-77572009000400008 
31. Samorodnitzky-Naveh GR, Geiger SB, Levin L. Patients' satisfaction with dental esthetics. J Am Dent Assoc. 2007 Jun;138(6):805-8. doi: 10.14219/jada. archive.2007.0269

32. Tin-0o MM, Saddki N, Hassan N. Factors influencing patient satisfaction with dental appearance and treatments they desire to improve aesthetics. BMC Oral Health. 2011Feb 23;11:6. doi:101186/1472-6831-11-6

33. Halawani SM, Al-Harbi SA. Marginal adaptation of fixed prosthodontics. IJMDC. 2017;1(2):78-84

34. Gaintantzopoulou MD, El-Damanhoury HM. Effect of preparation depth on the marginal and internal adaptation of computer-aided design/computerassisted manufacture endocrowns. Oper Dent. 2016 Nov/Dec;41(6):607-16. doi: 10.2341/15-146-L

35. Soliman KM, Mandor MH, El Mekkawi W. Marginal adaptation of lithium disilicate endocrowns with different cavity depths and margin designs. Al-Azhar D J. 2019;6(2):177-85

36. Forberger N, Göhring TN. Influence of the type of post and core on in vitro marginal continuity, fracture resistance, and fracture mode of lithia disilicatebased all-ceramic crowns. J Prosthet Dent. 2008;100(4):264-273. doi: 10.1016/S0022-3913(08)60205-X
37. Ramírez-Sebastià A, Bortolotto T, Cattani-Lorente M, Giner L, Roig M, Krejci I. Adhesive restoration of anterior endodontically treated teeth: influence of post length on fracture strength. Clin Oral Investig. 2014;18(2):545-54. doi: 10.1007/s00784-013-0978-3.

38. Creugers NH, Mentink AG, Fokkinga WA, Kreulen CM. 5-year follow-up of a prospective clinical study on various types of core restorations. Int $J$ Prosthodont. 2005;18(1):34-9.

39. Beck N, Graef F, Wichmann M, Karl M. In vitro fracture resistance of copymilled zirconia ceramic posts. J Prosthet Dent. 2010 Jan;103(1):40-4. doi: 10.1016/S0022-3913(09)60214-6.

40. Cormier CJ, Burns DR, Moon P. In vitro comparison of the fracture resistance and failure mode of fiber, ceramic, and conventional post systems at various stages of restoration. J Prosthodont. 2001 Mar;10(1):26-36. doi:10.1111/j.1532849x.2001.00026.x

41. Toksavul S, Toman M, Uyulgan B, Schmage P, Nergiz I. Effect of luting agents and reconstruction techniques on the fracture resistance of pre-fabricated post systems. J Oral Rehabil. 2005 Jun;32(6):433-40. doi: 10.1111//.13652842.2005.01438.x

\section{Amina A. ZAKI}

\section{(Corresponding address)}

Faculty of Dentistry- Cairo University and Head of the Fixed Prosthodontics Department -

Faculty of Oral and Dental Medicine, Egyptian Russian University, Cairo- Egypt

Email: aazaki99@yahoo.co.uk

Yasmin Abou EL-ENEIN

\section{(Corresponding address)}

Faculty of Oral and Dental Medicine- Egyptian Russian University- Cairo- Egypt.

Date submitted: 2020 Jul 26

Email: Yasmin.112@hotmail.com 